\title{
Pengaruh Suasana, Kualitas Makanan, dan Persepsi Nilai terhadap Kepuasan Pelanggan Rumah Makan Goa Sumbawa
}

\author{
Fendy Maradita), Mega Susilawati ${ }^{2}$ \\ 1) 2) Universitas Teknologi Sumbawa \\ Email:fendy.maradita@uts.ac.id ${ }^{l)}$,megasusilawati84@gmail.com²)
}

\begin{abstract}
This study aims to find out the influence of atmosphere, food quality, and perception of value on customer satisfaction. This research uses a type of Quantitative Associative research. The data collection method was carried out by distributing questionnaires to 100 respondents, namely customers at Sumbawa Goa Restaurant. Sampling techniques using non probability sampling and purposive sampling. Data analysisused is multiple linear regression analysis. Based on the results of the study, it can be concluded that the three free variables namely atmosphere, food quality and value perception have a positive and significant influence on restaurant customer satisfaction.
\end{abstract}

Keywords: Atmosphere, Food Quality, Value Perception

\begin{abstract}
Abstrak
Penelitian ini bertujuan untuk mengetahui pengaruh suasana, kualitas makanan, dan persepsi nilai terhadap kepuasan pelanggan Rumah Makan Goa Sumbawa . Penelitian ini menggunakan jenis penelitian Kuantitatif dengan pendekatan Asosiatif. Metode pengumpulandata dilakukan dengan membagikan kuesioner pada 100 responden, yaitu pelanggan di Rumah Makan Goa Sumbawa. Teknik pengambilan sampel menggunakan non probability sampling dengan metode purposive sampling. Analisis data yang digunakan yaitu analisis regresi linear berganda. Berdasarkan hasil penelitian dapat disimpulkan bahwa ketiga variabel bebas yaitu suasana, kualitas makanan dan persepsi nilai mempunyai pengaruh positif dan signifikan terhadap kepuasan pelanggan Rumah Makan Goa Sumbawa.
\end{abstract}

Kata Kunci: Suasana, Kualitas Makanan, Persepsi Nilai

\section{Pendahuluan}

Kondisi dunia bisnis saat ini dituntut untuk memenuhi apa yang menjadi kebutuhan dan permintaan masyarakat yang begitu dinamis. Segala tuntutan ini membuat pelaku usaha harus mampu membaca peluang ditengah persaingan usaha yang begitu pesat untuk dapat bertahan. Perkembangan dunia usaha sekarang ini terus mengalami peningkatan yang cukup cepat. Hal ini bisa dilihat dengan semakin banyaknya usaha- usaha yang berdiri, baik yang berskala kecil maupun yang berskala besar. Kondisi tersebut membuat pelaku usaha harus mampu terus bersaing dan bertahan melawan banyaknya pesaing yang ada. Banyaknya perusahaanperusahaan baru dalam dunia usaha yang bersaing dapat menjadikan kondisi persaingan antar perusahaan berlangsungsemakin ketat. Persaingan yang sangat ketat tersebut menuntut para pelaku usaha harus mampu menyusun strategi yang tepat yaitu dalam melakukan hal untuk pemenuhan kebutuhan konsumen yang begitu bervariasi (Putri Dkk, 2014).

Persaingan bisnis hampir terjadi pada semua jenis usaha, termasuk pada bisnis kuliner. Bisnis Kuliner bukan hanya dituntut menciptakan masakan yang enak tetapi harus mampu menciptakan nilai tambah yang lain dalam meningkatkan kepuasan konsumen.

Bisnis kuliner bukan hanya sekedar menawarkan makanan saja, tetapi harus mampu memberikan suasana yang menyenangkan, untuk membuat para pengunjung betah menikmati makanan dan menjadi tempat menghabiskan waktu bersama keluarga maupun kerabat yang menyenangkan . Kepuasan konsumen bukan hanya tercipta dari cita rasa makanan melainkan 
konsumen juga menginginkan suasana yang nyaman, bahkan konsumen dominan lebih memilih membeli makanan atau minuman yang menawarkan suasana yang nyaman daripada harus memilih membeli di restoran atau cafe yang hanya sekedar menjual makanan saja tanpa adanya suasana yang nyaman (Marinkovic Dkk, 2014).

Kualitas makanan juga dapat menjadi salah satu faktor penting bagi konsumen dalam menentukan kepuasannya. Kualitas merupakan titik awal bagi perusahaan dalam merebut pangsa pasar begitu juga pada bisnis kuliner. Suatu bisnis kuliner akan mencapai tingkat keberhasilannya apabila bisnis tersebut dapat mempertahankan kepuasan pelanggannya. Kepuasan pelanggan dapat dilihat juga dari sejauh mana kinerja suatu produk yang dirasakan cocok dengan harapanpelanggan, sehingga dapat menimbulkan perasaan senang atau perasaan kecewa yang dirasakan oleh seorang pelanggan (Saputra Dkk, 2016).

Di Kabupaten Sumbawa Besar sendiri, sudah banyak rumah makan yang sudah lama berdiri dan banyak juga muncul rumah makan baru yang tersebar hampir di seluruh wilayah kota Sumbawa Besar. Salah satunya berdiri sebuah restoran atau rumah makan yang berdiri dari bulan Januari 2007 yaitu Rumah Makan Goa yang berlokasi diKarang Dima, Labuhan Badas, Kab. Sumbawa Prov.Nusa Tenggara Barat. Rumah Makan Goa memiliki banyak pesaing usaha dibidang kuliner.

Rumah Makan yang terletak di arah barat kota Sumbawa ini, merupakan restoran bagi seluruh kalangan, baik kelas menengah kebawah sampai keatas. Rumah makan yang mengangkat suasana yang berkonsep Klasik Modern, rumah makan goa mempunyai interior yang mewah dan elegan, suasana hangat yang terpancar jelas, lewat kombinasi furniture klasik, dekorasi cantik, serta pencahayaan yang baik. Selain suasana yang begitu menarik, rumah makan goa menyajikan makanan dengan sajian menu makanan yang khas mulai dari makanan yang modern, Chinese food, serta makanan khas dari berbagai daerah di Kabupaten Sumbawa. Selain menawarkan suasana eksklusif yang klasik dan makanan yang dapat memuaskan pelanggan, rumah makan goa menyediakan layanan delivery, serta dalam hal pelayanan, rumah makan goa menyediakan fasilitas lain seperti tempat meeting, acara formal, dan sebagainya.

Berdasarkan pada latar belakang di atas, maka rumusan masalah dalam penelitian ini adalah sebagai berikut:

1. Bagaimanakah pengaruh suasana terhadap kepuasan pelanggan rumah makan Goa sumbawa?

2. Bagaimanakah kualitas makanan terhadap kepuasan pelanggan rumah makan Goa sumbawa?

3. Bagaimanakah pengaruh persepsi nilai terhadap kepuasan pelanggan rumah makan Goa sumbawa?

\section{Kajian Pustaka}

\subsection{Perilaku Konsumen}

Pengertian perilaku konsumen dapat diartikansebagai perilaku konsumen diperlihatkan oleh konsumen dalam mencari, membeli, menggunakan, dan menghabiskan produk dan jasa yang mereka harapkan, dapat memuaskan kebutuhannya. Perilaku konsumen mengacu kepada perilaku pembelian individu pembelian terakhir dan rumah tangga yang membeli barang atau jasa untuk konsumsi pribadi (Khodijah dan Saino, 2012). Jadi, dapat disimpulkan bahwa yang dimaksud dari perilaku konsumen merupakan suatu proses bagaimana konsumen dala memilih, 
membeli, menggunakan, kemudian mengevaluasi, dan menghabiskan produk untuk memenuhi kebutuhan dan keinginannya.

\subsection{Usaha Kuliner}

Indonesia yang dikenal dengan keanekaragaman budayanya, selain budaya Indonesia juga memiliki keanekaragaman dalam makanannya. Setiap sukuyang ada di Indonesia mempunyai masakan khas yangberbeda-beda dengan cita rasa yang bervariasi. Jika diolah dengan cara professional maka akan menjadi makanan khas dan sajian kuliner yang lezat, kuliner di Indonesia akan dapat meningkatkan pendapatan ekonomi masyarakat dan akan menjadi suatu identitas bangsa.

\subsection{Kepuasan Pelanggan}

Kepuasan pelanggan disebut filosofi bisnis yang cenderung dapat menciptakan nilai bagi seorangpelanggan, Kepuasan pelanggan merupakan faktor terpenting dalam berbagai kegiatan bisnis. Kepuasan pelanggan adalah tanggapan konsumen terhadap evaluasi ketidaksesuaian yang dirasakan antaraharapan yang sebelumnya dengan kinerja produk yangdirasakan dalam mengantisipasi dan mengelola harapan mereka serta dapat menunjukkan kemampuan dan tanggungjawab untuk memuaskan kebutuhan mereka (Gumussoy dan Koseoglu, 2016). Perilaku konsumen merupakan studi mengenai bagaimanaindividu, kelompok, dan organisasi dalam proses memilih, menggunakan, dan menghentikan produk, jasa, ide, dan pengalaman untuk memuaskan kebutuhannya dan dampaknya bagi masyarakat dan konsumen itu sendiri. Menurut Sangadji dan Sopiah (2013) dalam penelitiannya menyebutkan bahwa kepuasan diartikan sebagai adanya kesamaan antara kinerja produk dan pelayanan yang diterima dengan kinerja produk dan pelayanan yang diharapkan konsumen. Untuk mencapai tingkat kepuasan pelanggan, maka perusahaan harus tetap mempertahankan serta mengerti apa yang diinginkan oleh pelanggan, sehingga kebutuhan pelanggan akan selalu dipenuhi oleh perusahaan.

\subsection{Suasana}

Suasana (atmosphere) merupakan rancangan ruang yang dapat menghasilkan efek emosional tertentu bagi pembeli untuk lebih meningkatkan probabilitas pembeliannya (Hilaliyah Dkk, 2017). Setiap restoran memiliki penampilan yang berbeda- beda atau bervariasi baik dalam hal bersih, kotor, menarik, megah maupun suram. Restoran juga harus bisa menciptakan suasana yang sesuai dengan sasarannya juga dapat menarik pelanggan untukberkunjung ke restoran tersebut.

\subsection{Kualitas Makanan}

Kualitas tidak hanya terdapat pada barang atau jasa, tetapi juga terdapat di dalam produk makanan. Kualitas makanan merupakan suatu tingkatan dalam konsistensi kualitas menu yang dicapai dengan penetapan suatu standar produk dan kemudian mengecek poin-poin yang harus dikontrol untukmelihat kualitas yang ingin dicapai (Hanisah, 2017).

\subsection{Persepsi Nilai}

Kotler \& Keller (2016), menyatakan bahwa persepsi adalah proses yang digunakan oleh individu untuk memilih, mengorganisasi, dan menginterpretasi masukan informasi guna menciptakan gambaran dunia yang memiliki arti. Nilai pelanggan merupakan kombinasi kualitas, pelayanan, harga dari suatu penawaran produk. Nilai pada pelanggan adalah selisih antara jumlah nilai bagi pelanggan dan jumlah biaya dari pelanggan, dan jumlah nilai bagi pelanggan adalah sekelompok keuntungan yang diharapkan pelanggan dari barang atau 


\subsection{Kerangka Pemikiran dan Hipotesis Penelitian}

Variabel yang dianalisis adalah variabel independen yaitu suasana, kualitas makanan dan persepsi nilai (variabel X1, X2, dan X3) sedangkan variabel dependen adalah kepuasan pelanggan (variabel $\mathrm{Y}$ ). Pengujian yang dilakukan adalah untuk mengetahui pengaruh variabel independen $\mathrm{X} 1, \mathrm{X} 2$, danX3 terhadap $\mathrm{Y}$.

Gambar 1. Kerangka Pemikiran Penelitian

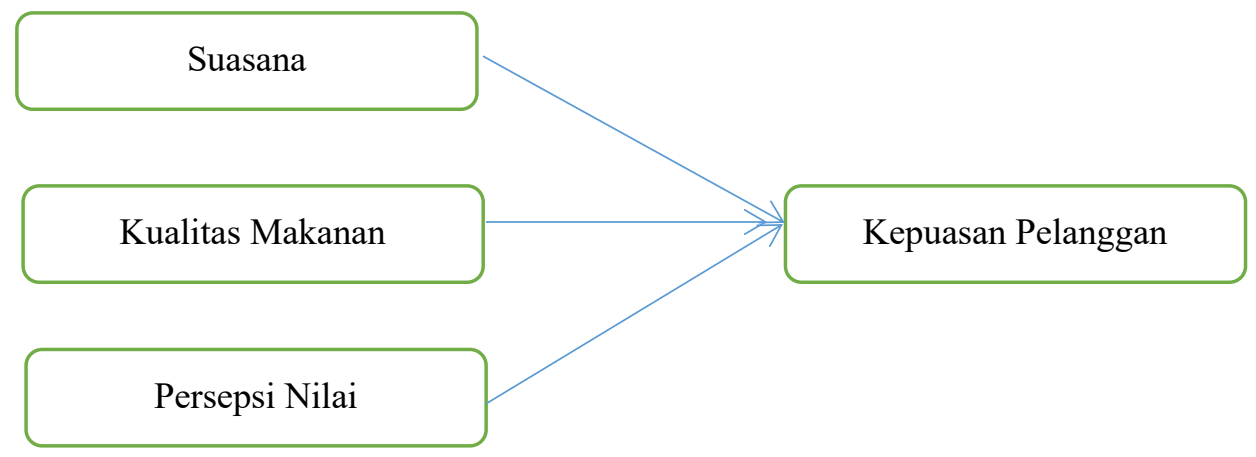

Hipotesis

H1: Suasana Berpengaruh Positif dan Signifikan Terhadap Kepuasan Pelanggan Rumah Makan Goa Sumbawa.

H2: Kualitas Makanan Berpengaruh Positif dan Signifikan Terhadap Kepuasan Pelanggan Rumah Makan Goa Sumbawa.

H3: Persepsi Nilai Berpengaruh Positif dan Signifikan Terhadap Kepuasan Pelanggan Rumah Makan Goa Sumbawa.

\section{Metode Penelitian}

\subsection{Jenis Penelitian}

Jenis penelitian ini menggunakan penelitian kuantitatif dengan pendekatan asosiatif. Penelitian kuantitatif yaitu penelitian yang lebih berdasarkan pada data yang dapat dihitung untuk mendapatkan penaksiran (Sugiyono, 2014). Sedangkan penelitian asosiatif adalah penelitian yang bertujuan untuk menguji hubungan atau pengaruh variable bebas terhadap variable terikat.

\subsection{Populasi dan Sampel Penelitian}

Populasi merupakan wilayah generalisasi atas objek atau subjek dengan kualitas dan karakteristik tertentu dengan yang ditetapkan oleh peneliti untukdipelajar dan kemudian diambil kesimpulan(Sugiyono, 2019) Populasi dalam penelitian ini adalahmasyarakat yang berdomisili di kabupaten sumbawa yang menjadi Pelanggan Rumah Makan Goa. Dalam penelitian ini jumlah populasi sangat besar dan tak bisa dipastikan jumlahnya secara pasti. Maka dilakukan pengambilan sampel menggunakan Non probability sampling dengan metode purposive sampling yaitu pengambilan dengan pertimbangan tertentu. (Sugiyono, 2014). Teknik sampling menggunakan rumus Paul Leedy dalam Arikunto (2006), dengan hasil perhitungan yaitu 100 responden dijadikan sebagai sampel penelitian. 


\subsection{Variabel penelitian dan definisi operasional variabel penelitian}

Menurut Sugiyono (2014) definisi operasional variable penelitian merupakan segala sesuatu yang berbentuk apa saja yang ditetapkan oleh peneliti untuk dipelajari sehingga, diperoleh informasi tentang hal tersebut kemudian ditarik kesimpulan. penelitian ini terdiri dari variabel independen yaitu suasana (X1), kualitas makanan (X2), persepsi nilai (X3) dan variabel independen yaitu kepuasan pelanggan resto $(\mathrm{Y})$.

Tabel 1. Definisi Operasional Variabel

\begin{tabular}{|c|c|c|}
\hline Variabel & Definisi & Indikator \\
\hline Suasana & $\begin{array}{l}\text { Suasana (atmosphere) } \\
\text { merupakan suaturancangan } \\
\text { ruang untukmenghasilkan efek } \\
\text { emosional tertentu padapembeli } \\
\text { untukmeningkatkan probabilitas } \\
\text { pembeliannya. }\end{array}$ & $\begin{array}{l}\text { a. } \\
\text { b. } \\
\text { c. } \text { Wahaya ruangan yangcukup } \\
\text { d. Musik yangsesuai suasana } \\
\text { e. Suhu ruangan sejuk }\end{array}$ \\
\hline Kualitas Makanan & $\begin{array}{l}\text { Kualitas makanan merupakan suatu } \\
\text { tingkatan dalam konsistensi } \\
\text { kualitas menuyang dicapai dengan } \\
\text { penetapan suatu standar produk dan } \\
\text { kemudianmengecek poin-poin yang } \\
\text { harus dikontrol untuk melihat } \\
\text { kualitas yang ingin dicapai. Faktor } \\
\text { utama yang membuat pelanggan } \\
\text { tertarik untukmencoba berkunjung } \\
\text { ke sebuah restoran Atau caféyaitu } \\
\text { karena makanan yang } \\
\text { ditawarkannya. }\end{array}$ & $\begin{array}{l}\text { a. Variasi jenis makanan } \\
\text { bermacam-macam } \\
\text { b. Cita rasa khas } \\
\text { c. Sajian makanan lezat } \\
\end{array}$ \\
\hline Persepsi Nilai & $\begin{array}{l}\text { perceived value sebagai penilaian } \\
\text { konsumen secara keseluruhan } \\
\text { terhadap kegunaan suatu produk } \\
\text { atau jasa berdasarkan } \\
\text { persepsi atas apa yang telah didapat. }\end{array}$ & $\begin{array}{ll}\text { a. } & \text { Emotional Value } \\
\text { b. } & \text { Social Value } \\
\text { c. } & \text { Performance } \\
\text { d. } & \text { Price/value of money }\end{array}$ \\
\hline Kepuasan Pelanggan & $\begin{array}{l}\text { Kepuasan pelanggan merupakan } \\
\text { tingkatan perasaan konsumen } \\
\text { setelah membandingkan kinerja } \\
\text { atau hasil produk yang ia rasakan } \\
\text { dengan harapannya. }\end{array}$ & $\begin{array}{l}\text { a. Kualitas makanan sesuai } \\
\text { dengan harapan pelanggan } \\
\text { b. Kualitas pelayanan sesuai } \\
\text { dengan harapan } \\
\text { c. Pengalaman yang } \\
\text { menyenangkan }\end{array}$ \\
\hline
\end{tabular}




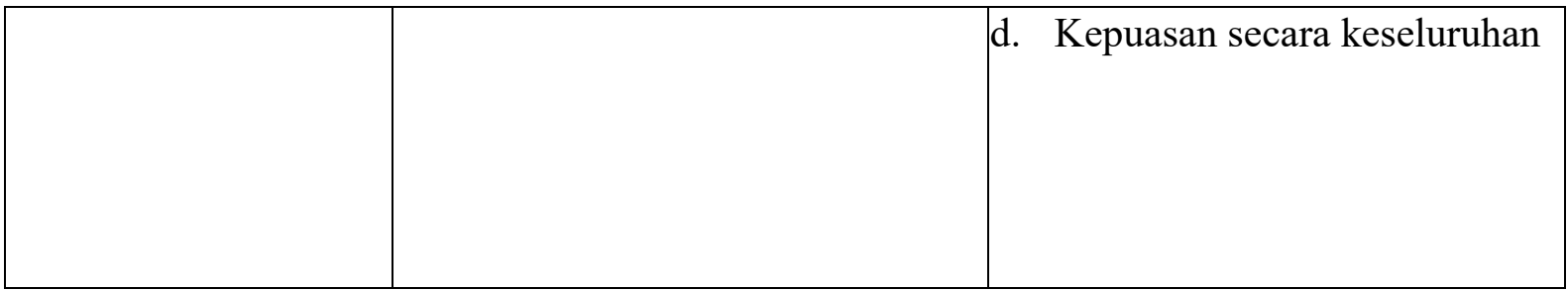

\subsection{Teknik Pengumpulan Data}

Teknik pengumpulan data yang digunakan adalah dengan menggunakan kuesioner yaitu dilakukan dengan menyebar daftar pertanyaan kepada pelanggan Rumah Makan Goa yang menjadi sampel dari populasi penelitian. Jawaban dari setiap item pertanyaan menggunakan skala likert. Terdapat 4 (empat) pilihan dalam skala likert sebagi berikut :

Tabel 2. Skala likert

\begin{tabular}{|l|c|}
\hline \multicolumn{1}{|c|}{ Keterangan } & Skor \\
\hline Sangat Setuju (SS) & 4 \\
\hline Setuju (S) & 3 \\
\hline Tidak Setuju (TS) & 2 \\
\hline Sangat Tidak Setuju (STS) & 1 \\
\hline
\end{tabular}

\subsection{Teknik Analisis Data}

Sebelum kuesioner disebarkan kepada responden, terlebih dahulu akan dilakukan uji instrumen penelitian. Uji instrumen penelitian ini terdiri dari uji validitas dan uji reliabilitas. Uji validitas digunakan untuk menguji isi dari suatu instrumen penelitian, dengan tujuan untuk mengukur valid atau tidaknya suatu kuesioner, sedangkan uji reliabelitas menguji digunakan untuk mengukur ketepatan instrumen sehingga menghasilkan data yang dapat dipercaya dalam penelitian. Metode analisis data yang digunakan dalam penelitian ini adalah meliputi uji asumsi klasik, uji analisis regresi linier berganda, uji hipotesis, dengan menggunakan aplikasi statistical package for social science (SPSS).

\section{Hasil Penelitian dan Pembahasan}

Penelitian ini dilakukan dengan menyebarkan kuesioner pada pelanggan Rumah Makan Goa yang berdomisili di Kota Sumbawa Besar dengan jumlah responden sebanyak 100 responden.

Adapun karakteristik responden yang telah ditetapkan sebagai berikut :

1. Masyarakat yang berdomisili di Kota Sumbawa Besar

2. Telah melakukan pembelian lebih dari 2 kali

3. Melakukan pembelian dalam 6 bulan terakhir

\subsection{Hasil Uji Instrumen Penelitian}

\subsubsection{Hasil Uji Validitas}


Sebelum kuesioner dibagikan kepada responden terlebih dahulu dilakukan uji validitas terhadap instrumen penelitian. Uji validitas digunakan untuk menguji ketepatan dan kesahihan instrumen penelitian, untuk mengetahui valid atau tidaknya instrumen penelitian yaitu dengan membandingkan nilai $r$ hitung dengan $r$ tabel. Apabila $r$ hitung lebih besar dari $r$ tabel maka butir pernyataan valid dan dapat digunakan dalam kuesioner penelitian.

Tabel 3. Hasil Uji Validitas

\begin{tabular}{|c|c|c|c|c|c|}
\hline Variabel Penelitian & Butir Instrumen & $\begin{array}{l}\text { Nilai } r \\
\text { hitung }\end{array}$ & $\begin{array}{c}\text { Nilai } r \\
\text { tabel }\end{array}$ & Sig & Ket. \\
\hline \multirow{6}{*}{ Suasana } & 1 & 0.612 & 0.195 & 0.000 & Valid \\
\hline & 2 & 0.810 & 0.195 & 0.000 & Valid \\
\hline & & & & & \\
\hline & 3 & 0.669 & 0.195 & 0.000 & Valid \\
\hline & 4 & 0.678 & 0.195 & 0.000 & Valid \\
\hline & 5 & 0.409 & 0.195 & 0.000 & Valid \\
\hline \multirow{6}{*}{ Kualitas Makanan } & 1 & 0.446 & 0.195 & 0.000 & Valid \\
\hline & 2 & 0.568 & 0.195 & 0.000 & Valid \\
\hline & 3 & 0.867 & 0.195 & 0.000 & Valid \\
\hline & 4 & 0.809 & 0.195 & 0.000 & Valid \\
\hline & 5 & 0.371 & 0.195 & 0.000 & Valid \\
\hline & 6 & 0.867 & 0.195 & 0.000 & Valid \\
\hline \multirow{3}{*}{ Persepsi Nilai } & 1 & 0.685 & 0.195 & 0.000 & Valid \\
\hline & 2 & 0.720 & 0.195 & 0.000 & Valid \\
\hline & & & & & \\
\hline
\end{tabular}




\begin{tabular}{|c|c|c|c|c|c|}
\hline & 3 & 0.722 & 0.195 & 0.000 & Valid \\
\hline & 4 & 0.688 & 0.195 & 0.000 & Valid \\
\hline & 5 & 0.732 & 0.195 & 0.000 & Valid \\
\hline \multirow{6}{*}{ Kepuasan Pelanggan } & 1 & 0.466 & 0.195 & 0.000 & Valid \\
\hline & 2 & 0.568 & 0.195 & 0.000 & Valid \\
\hline & 3 & 0.867 & 0.195 & 0.000 & Valid \\
\hline & 4 & 0.809 & 0.195 & 0.000 & Valid \\
\hline & 5 & 0.371 & 0.195 & 0.000 & Valid \\
\hline & 6 & 0.867 & 0.195 & 0.000 & Valid \\
\hline
\end{tabular}

Berdasarkan uji validitas yang dilakukan, dapat dilihat semua butir pernyataan pada semua variabel dinyatakan valid. Hal tersebut dapat diketahui dengan mambandingkan nilai $r$ hitung dengan $r$ tabel, pada semua butir pernyataan nilai $r$ hitung $>r$ tabel maka semua butir pernyataan pada semua variabel penelitian valid dan dapat digunakan sebagai kuesioner penelitian.

\subsubsection{Hasil Uji reliabilitas}

Uji reliabelitas digunakan untuk memastikan bahwa apakah kuesioner yang akan digunanakan dalam penelitian reliabel atau tidak, atau dalam artian instrumen yang akan digunakan bisa dipakai berulang kali dan mendapat hasil yang konsisten. Untuk mengetahui reliabel atau tidak instrumen penelitian dapat dibandingkan nilai Cronbach's Alpha, apabila nilai Cronbach's Alpha lebih dari 0,60 maka kuesioner dikatakan reliabel.

Tabel 4. Hasil Uji Reliabilitas

\begin{tabular}{|l|c|c|c|}
\hline Variabel & Koefisien & Taraf & Keterangan \\
& alpha & signifikansi & \\
\hline Suasana & 0,620 & 0,60 & Reliabel \\
\hline Kualitas Makanan & 0,763 & 0,60 & Reliabel \\
\hline Persepsi Nilai & 0,746 & 0,60 & Reliabel \\
\hline Kepuasan Pelanggan & 0,763 & 0,60 & Reliabel \\
\hline
\end{tabular}

Berdasarkan hasil uji reliabilitas yang dilakukan, didapatkan hasil perhitungan semua variabel penelitian memiliki nilai diatas 0,60. Maka dapat disimpulkan semua instrumen penelitian dalam penelitian dinyatakan reliabel dan dapat digunakan dalam penelitian. 


\subsection{Hasil Uji Asumsi Klasik}

Uji asumsi klasik bertujuan untuk mengetahui kondisi data yang dipergunakan dalam penelitian.Hal tersebut dilakukan untuk diperoleh model analisis yang tepat (Ghozali, 2011). Adapun uji asumsi klasik yang dilakukan adalah sebagai berikut :

\subsubsection{Normalitas Data}

Uji normalitas bertujuan untuk menguji apakah dalam model regresi variabel terikat, variabel bebas atau keduanya mempunyai distribusi normal atau tidak. Pengukuran yang digunakan adalah membandingkan nilaiasymp.Sig (2-tailed) dengan nilai yang ditentukan sebesar 5\%. Apabila nilai asymp. Sig (2-tailed) lebih besar dari 0,05 makadapat disimpulkan bahwa data tersebut berdistribusi normal. Hasil uji normalitas adalah sebagai berikut:

Tabel 5 Hasil Uji Normalitas One-Sample Kolmogorov-Smirnov Test

\begin{tabular}{|ll|r|}
\hline & & \multicolumn{2}{|c|}{$\begin{array}{c}\text { Unstandardized } \\
\text { Residual }\end{array}$} \\
\hline N & Mean & 100 \\
Normal & Std. Deviation & $0 \mathrm{E}-7$ \\
Parameters & & \\
b & Absolute & 3.26630975 \\
Most Extreme & Positive & .091 \\
Differences & Negative & .078 \\
& & -.091 \\
Kolmogorov-Smirnov Z & .910 \\
Asymp. Sig. (2-tailed) & .379 \\
\hline
\end{tabular}

Berdasarkan hasil uji normalitas yang dilakukan, nilai Asymp. Sig. (2-tailed) yaitu sebesar 0,379 lebih besar dari 0,05 maka dapat disimpulkan data berdistribusi normal.

\subsubsection{Uji Multikolinearitas}

Uji multikolinearitas bertujuan untuk mengetahui apakah terdapat gejala korelasi antar variabel independen lainnya. Pemeriksaan untuk mendeteksi gejala multikolinieritas dilakukan dengan melihat nilai tolerance dan VIF (Variance Inflation Factor) yang dihitung dengan menggunakan SPSS Statisic 16 for window. Hasil uji multikolinieritas disajikan dalam tabel berikut: 
Tabel 6. Uji Multikolinearitas

\begin{tabular}{|c|l|c|c|}
\hline \multirow{2}{*}{ No } & \multicolumn{1}{|c|}{ Variabel } & \multicolumn{2}{c|}{ Collinearity statistics } \\
\cline { 3 - 4 } & & Tolerance & VIF \\
\hline 1 & Suasana (X1) & .173 & 5.776 \\
\hline 2 & Kualitas Makanan (X2) & .661 & 1.513 \\
\hline 3 & Persepsi Nilai (X3) & .151 & 6.629 \\
\hline
\end{tabular}

Tabel tersebut menunjukkan bahwa semua variabel independen memiliki nilai tolerance $>0,1$ dan nilai VIF $<10$, maka dapat disimpulkan tidak terdapat masalah multikolinearitas.

\subsubsection{Uji Heteroskedastisitas}

Heteroskedastisitas yakni menunjukan bahwa adanya varian variabel tidak sama untuk semua observasi. Untuk mendeteksi ada atau tidaknya heteroskedastisitas dalam penelitian ini menggunakan pengujian Glejser dengan syarat jika nilai Sig. diatas 0.05 maka tidak terjadi heteroskedastisitas. Hasil uji heteroskedastisitas dapat dilihat pada tabel berikut :

Tabel 7. Hasil Uji Heteroskedastisitas

\begin{tabular}{|l|c|c|l|}
\hline Variabel & \multicolumn{1}{|l|}{ Sig } & \multicolumn{1}{l|}{ Standar } & Keterangan \\
\hline Suasana & 0,601 & 0,05 & Tidak Terjadi heteroskedastisitas \\
\hline Kualitas Makanan & 0,748 & 0,05 & Tidak Terjadi heteroskedastisitas \\
\hline Persepsi Nilai & 0,552 & 0,05 & Tidak Terjadi heteroskedastisitas \\
\hline
\end{tabular}

\subsection{Hasil Uji Regresi Linier Berganda}

Analisis regresi linear berganda digunakan untuk mengetahui pengaruh suasana $\left(\mathrm{X}_{1}\right)$, Kualitas Makanan $\left(\mathrm{X}_{2}\right)$ dan Persepsi Nilai $\left(\mathrm{X}_{3}\right)$ terhadapKepuasan Pelanggan (Y). Hasil Analisis regresi linier berganda adalah sebagai berikut:

Tabel 8. Hasil Regresi Linier Berganda

\begin{tabular}{|l|l|c|l|l|l|}
\hline \multirow{2}{*}{ Model } & \multicolumn{2}{|c|}{} & $\begin{array}{l}\text { Standardi } \\
\text { zed } \\
\text { Unstandardized } \\
\text { Coefficients }\end{array}$ & $\begin{array}{l}\text { Coefficie } \\
\text { nts }\end{array}$ & Sig. \\
\cline { 2 - 6 } & B & $\begin{array}{c}\text { Std. } \\
\text { Error }\end{array}$ & Beta & & \\
\hline
\end{tabular}




\begin{tabular}{|c|c|c|c|c|c|}
\hline (Constant) & 16.120 & 2.989 & & 5.394 & .000 \\
\hline SUASANA & .468 & .186 & .269 & 2.519 & .013 \\
\hline KUALITAS & & & & & \\
\hline MAKANAN & .265 & .109 & .253 & 2.431 & .017 \\
\hline PERSEPSI NILAI & .266 & .133 & .198 & 1.992 & .049 \\
\hline
\end{tabular}

Berdasarkan hasil analisis regresi pada maka dapat diketahui persamaan regresi sebagai berikut:

$$
Y=16,120+0,468 X_{1}+0,265 X_{2}+0,266 X_{3}+e
$$

Hasil persamaan regresi berganda di atas dapat memberikan pengertian sebagai berikut:

a. Nilai konstanta sebesar 16,120 menunjukkan bahwa ketika nilaivariabel independen yaitu variabel suasana, kualitas makanan dan persepsi nilai diasumsikan diabaikan, maka nilai kepuasan pelanggan sebesar 16,120 .

b. Nilai koefisien regresi variabel suasana bernilai positif yaitu 0,468 menunjukkan apabila nilai suasana mengalami kenaikan satu satuan sementara variabel independen lainnya diasumsikan tetap, maka nilai kepuasana pelanggan akan meningkat sebesar 0,468.

c. Nilai koefisien regresi variabel kualitas makanan bernilai positif yaitu 0,265 menunjukkan apabila nilai kualitas makanan mengalamikenaikan satu satuan sementara variabel independen lainnya diasumsikan tetap, maka nilai kepuasan pelanggan akan meningkat sebesar 0,265.

d. Nilai koefisien regresi variabel persepsi nilai bernilai positif yaitu 0,266 menunjukkan apabila nilai persepsi nilai mengalami kenaikansatu satuan sementara variabel independen lainnya diasumsikan tetap, maka nilaikepuasan pelanggan akan meningkat sebesar 0,266.

\subsection{Hasil Uji T ( Parsial)}

Pengujian menggunakan tingkat signifikansi 0,05. Jika nilai sig. $>0,05$ maka Ho diterima dan Ha ditolak sedangkan jika nilai sig. $<0,05$ maka Ho ditolak dan Ha diterima.

Berdasarkan hasil analisis penjelasan masing-masing variabel terhadap kepuasan pelanggan restoran adalah sebagai berikut:

a. Variabel Suasana

Berdasarkan Tabel 8 di atas dapat dilihat bahwa nilai thitung variabel suasana sebesar 2,519 dimana thitung $>\operatorname{ttabel}(2,519>1,984)$ dengan nilai signifikansi $0,013<0,05$. Maka Ho ditolak dan Ha di terima, sehingga dapatdisimpulkan bahwa terdapat pengaruh positif yang signifikan antara suasana dan kepuasan pelanggan.

\section{b. Variabel Kualitas Makanan}

Berdasarkan Tabel 8 di atas dapat dilihat bahwa nilai thitung variabel Kualitas Makanan 2,431 dimana thitung $>$ ttabel $(2,431>1,984)$ dengan nilai signifikansi $0,017<0,05$. Maka Ho ditolak dan Ha diterima, sehingga dapat disimpulkan bahwa terdapat pengaruh positif dan signifikan antara kualitas makanan dengan kepuasan pelanggan. 


\section{c. Variabel Persepsi Nilai}

Berdasarkan hasil uji t yang dilakukan, bahwa nilai thitung variabel persepsi nilai 2,431 dimana thitung $>$ ttabel $(1,992>1,984)$ dengan nilai signifikansi $0,049<0,05$. Maka Ho ditolak dan Ha diterima, sehingga dapat disimpulkan bahwa terdapat pengaruh positif yang signifikan antara persepsi nilai dengan kepuasan pelanggan.

\subsection{Pembahasan}

\subsubsection{Pengaruh suasana terhadap kepuasan pelanggan Rumah Makan Goa Sumbawa}

Hasil dari penelitian ini yang dilakukan oleh peneliti pada studi kasus Rumah Makan Goa menunjukkan bahwa suasana Restoran berpengaruh positif dan signifikan terhadap loyalitas konsumen, dapat dilihat bahwa nilai thitung variabel suasana sebesar 2,519 dimana thitung $>$ ttabel $(2,519>1,984)$ dengan nilai signifikansi $0,013<0,05$. yang berarti bahwa semakin menarik suasana restoran yang ditawarkan maka konsumen dan pelanggan juga akan semakin loyal. Artinya Rumah Makan Goa mampu memberikan suasana restoran yang menarik dan sesuai dengan harapan pelanggan. Suasana (atmosphere) merupakan faktor penting bagi restoran atau cafe untuk dapat membuat pelanggan merasatertarik berkunjung dan nyaman dalam membeli makanan atau minuman (Alfin dan Nurdin, 2017). Hasil penelitian yang dilakukan oleh peneliti didukung dengan penelitian sebelumnya yang dilakukan oleh Salsabilah dan Sunarti (2018) bahwa suasana berpengaruh signifikan terhadap kepuasan pelanggan sehingga hipotesis pertama (HI) diterima.

\subsubsection{Pengaruh kualitas makanan terhadap kepuasan pelanggan Rumah Makan Goa Sumbawa}

Hasil penelitian ini menunjukan bahwahubungan kualitas makanan dengan kepuasan pelanggan positif dan signifikan, dapat dilihat bahwa nilai thitung variabel Kualitas Makanan 2,431 dimana thitung $>\operatorname{ttabel}(2,431>1,984)$ dengan nilai signifikansi $0,017<0,05$. Artinya semakin baik kualitas makanan maka akan meningkatkan kepuasan pelanggan. Menurut penelitian (Wijaya, 2013). 'mempertahankan tingkat kualitas makanan yang tinggi mutlak diperlukan untuk memenuhi kebutuhan dan harapan pelanggan restoran'. Pelanggan akan tertarik pada kualitas makanan yang ditawarkan oleh sebuah restoran atau rumah makan. Faktor utama yang membuat pelanggan tertarik untuk mencoba berkunjung ke sebuah restoran atau rumah makan yaitu karena makanan yang ditawarkannya (Sugianto dan Sugiharto, 2013), sehingga hipotesis (H2) diterima.

\subsubsection{Pengaruh Persepsi Nilai TerhadapKepuasan Pelanggan Rumah Makan Goa Sumbawa}

Hasil dalam penelitian ini mengenai PersepsiNilai dengan kepuasan pelanggan restoran positif dansignifikan, dapat dilihat bahwa nilai thitung variabel persepsi nilai 2,431 dimana thitung > ttabel $(1,992>1,984)$ dengan nilai signifikansi $0,049<0,05$, Artinyasemakin baik pelayanan yang diberikan semakin tinggi juga persepsi nilai yang dirasakan oleh pelanggan. Woodruff (2017) menyatakan bahwa nilai konsumen adalah pilihan yang dirasakan pelanggan dan evaluasi terhadap atribut produk dan jasa, kinerja atribut dan konsekuensi yang timbul dari penggunaanproduk untuk mencapai tujuan dan maksud konsumen ketika menggunakan produk artinya Hipotesis (H3) diterima

\section{Kesimpulan dan Saran}

\subsection{Kesimpulan}

Berdasarkan hasil penelitian yang telah dilakukan maka dapat disimpulkan bahwa : 
1. Suasana memberikan pengaruh yang positif dansignifikan terhadap kepuasan pelanggan di RumahMakan Goa Sumbawa. Semakin baik suasana yang diberikan maka semakin baik dan berpengaruh juga dengan kepuasan pelanggan. Hal ini menunjukan bahwa suasana direstoran tersebut dapat memenuhi kepuasan pelanggan.

2. Kualitas Makanan memberikan pengaruh yang positif dan signifikan terhadap kepuasan pelanggan di Rumah Makan Goa. Semakin baik kualitas makanan yang diberikan makan semakin baik pengaruhnya untuk pelanggan atau pengunjung. Artinya, kualitas makanan di Rumah Makan Goa telah memberikan kepuasan kepada pelanggan dan sudah tidak diragukan lagi dalam hal kualitas makanan.

3. Persepsi nilai atau nilai atau hasil yang didapatkan oleh pelanggan mempunyai pengaruh yang positif dan signifikan terhadap kepuasan pelanggan di Rumah Makan Goa Sumbawa. Semakinbaik pelayanan yang diberikan makan sangat berpengaruh terhadap persepsi nilai atau hasil yang didapatkan oleh pelanggan. Hal ini menunjukan, apabila segala pelayanan yang diberikan oleh Rumah makan goa telah baik dan memberikan pengaruh positif terhadap kepuasan pelanggan.

\subsection{Saran}

1. Bagi peneliti selanjutnya, diharapkan penelitianini dapat menjadi refrensi dan masukan untukmenambah wawasan. Peneliti menyarankan untuk mengkaji dan menambah maupun mencari referensi tentang bagaimana restoran ini agar penelitian selanjutnya dapat lebih baik dan lebih lengkap lagi.

2. Bagi perusahaan diharapkan agar tetap menjaga, meningkatkan dan mempertahankan suasana dan kualitas makanan yang selama ini dapat meningkatkan kepuasan pelanggan.

\section{Referensi}

Arikunto, S. (2006). Metode Penelitian. Jakarta : Bumi Aksara

Alfin, M. R., \& Nurdin, S. (2017). Pengaruh Store Atmosphere Pada Kepuasan Pelanggan YangBerimplikasi Pada Loyalitas Pelanggan. Jurnal Ecodemica, 1(2), 240-249.

Ghozali, I. (2013). Aplikasi Analisis Multivariate dengan Program IBM SPSS 21 (7th ed.). Semarang: Badan Penerbit Universitas Diponegoro.

Hanaysha, J. (2016). Testing the Effects of Food Quality, Price Fairness, and Physical Environment on Customer Satisfaction in Fast Food Restaurant. Ind Asian Economic and Social Society, 6(2), 31-40.

Hanisah.(2017). Kepuasan Pengunjung Terhadap Kualitas Lendot di Kawasan Wisata Taman Kota Coastal Area Kabupaten Karimun, 4(2), 1-10.

Kotler dan Keller, 2016, Manajemen Pemasaran, Edisi 12, Jilid 1, PT. Indeks.

Kotler, P., \& Keller, kevin L. (2008). Manajemen Pemasaran. (S. Bob, Ed.) (Edisi 13j). Jakarta : Erlangga. Layanan dan Kualitas Produk yangdi Moderasi oleh Suasana Terhadap Kepuasan Pelanggan (Studi Pada Mahasiswa Pelanggan Kafe Ria Djenaka Malang). Jurnal Bisnis DanManajemen, 4(2), 172-187.

Marinkovic, V., Senic, V., Danijela, I., Darko, D., \& Marija, B. (2014). The antecedents of satisfaction and revisit intentions for full-service restaurants. Marketing Intelligence \& 


\section{Planning, 32, 311-327.}

Nurdiansyah, M. D., \& Matadji. (2016). Pengaruh Kualitas Layanan, Harga dan Atmosfer Toko Terhadap Kepuasan Pelanggan Toko Buku Togamas Gajah Mada Sidoarjo. Jurnal Ekonomi Manajemen, 1(1),29-44.

Putri, L. H., Srikandi Kumadji, \& Kusumawati, A. (2014). Pengaruh Store Atmosphere Terhadap Keputusan Pembelian dan Kepuasan Pelanggan ( Studi pada Monopoli Cafe and Resto Soekarno Hatta Malang). Jurnal Administrasi Bisnis, 15(2).

Sanusi, Anwar. (2012). Metode Penelitian Bisnis. Jakarta: Salemba Empat.

Saputra, K. A., Hariyani, \& Rafani, Y. (2016). Analisis Pengaruh Kualitas Makanan dan Pelayanan Terhadap Kepuasan Pelanggan ( Studi Kasus Di Rumah Makan Bareh Solok Pangkalpinang ). Jurnal Ilmiah Progresif Manajemen Bisnis, 14(November), 37-45.

Sugianto, J., \& Sugiharto, S. (2013). Analisa Pengaruh Service Quality, Food Quality dan Price Terhadap Kepuasan Pelanggan Restoran Yung Ho Surabaya. Jurnal Manajemen Pemasaran Petra, 1(2), 1-10.

Sugiyono. (2014). Metode Penelitian Pendidikan (Pendekatan Kuantitatif, Kualitatif, dan $R \& D)$. Bandung: Alfabeta."

Sugiyono. (2019). Statistika untuk Penelitian. Bandung: ALFABETA.

Wijaya, W., \& Petra, U. K. (2013). Analisa Pengaruh Kualitas Makanan Terhadap Kepuasan Konsumen di Yoshinoya Galaxy Mall Surabaya. Jurnal Bisnis Dan Manajemen, 581-594.

Woodruff, B, Robert., 2017, “Customer Value: The Next Source for Competitive Advantage”, Journal of Marketing Sience, Vol. 25, Hal. 139-153. 